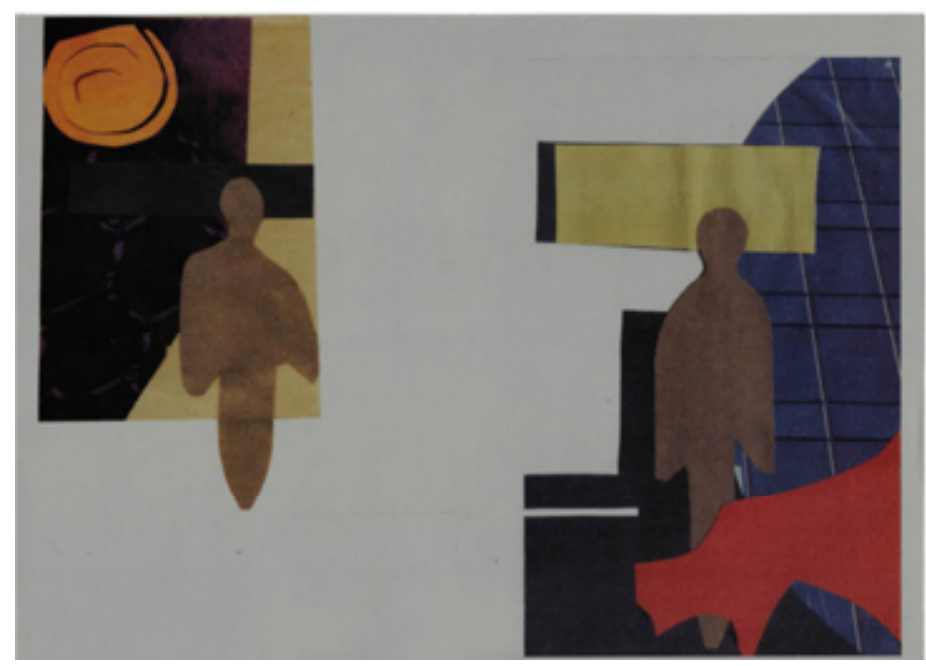

Ilustração Luciana Diniz

\title{
Bóris e Dóris: um flagrante cotidiano
}

\section{Jairo Rodrigues}

Jairo Rodrigues é Mestre em Estudos Literários pela Faculdade de Letras da UFMG e coordenador do setor de Bibliotecas Comunitárias do Programa de Ensino, Pesquisa e Extensão A tela e o texto.

\section{VILELA, Luiz. Bóris e Dóris. Rio de Janeiro: Record, 2006.}

Natural de Ituiutaba (MG), onde vive atualmente, o escritor Luiz Vilela iniciou sua carreira em 1967, aos 24 anos de idade, com o volume de contos Tremor de terra. O livro de estréia conferiu ao autor o primeiro dos muitos prêmios que receberia por sua obra, pois tremor de terra ganhou, naquele mesmo ano, o Prêmio Nacional de Ficção, em Brasilia.

Excetuando-se as antologias, Luiz Vilela escreveu, entre contos, novelas e romances, treze títulos. O mais recente, lançado em 2006, é Bóris e Dóris, sua terceira novela. Nela, o autor reafirma uma das habilidades mais marcantes em sua escrita, "sua capacidade", como afirma Laís Corrêa Araújo, "de apreender a consciência das relações humanas e de integrá-la numa organização estética". Ao lançar seu 
olhar perquiridor sobre as relações humanas, Vilela parece não buscar os grandes acontecimentos, os temas comoventes e apaixonantes. Em vez de mirar uma luneta para o espaço na tentativa de descobrir novas constelações, o autor direciona sua lupa para as situações corriqueiras que passam despercebidas justamente porque são tão cotidianas.

A aparente simplicidade temática, no entanto, mais parece uma estratégia para esconder a extrema maestria com que o escritor elabora sua narrativa. A linguagem, quase sempre informal é, em muitos casos, disposta em diálogos, reproduzindo a fala. Contudo, engana-se quem pensa que seus personagens falam demais. Em Vilela, o que sobra não são as palavras. Há sempre algo que ele não contou, já que muitos de seus textos são recortes no tempo. Vilela é sucinto e deixa para o leitor as conjecturas sobre o que teria acontecido antes ou depois do texto.

Em Bóris e Dóris, esse recorte temporal é claro. A história se passa durante um dia na vida dos protagonistas. Como eles chegaram àquela situação e o que acontecerá depois, fica a cargo de cada leitor. Os nomes dos personagens, entretanto, são informações bastante reiteradas pelo autor, já que compõem o título do livro, sobre eles, é interessante destacar que se diferenciam apenas pela alteração da primeira consoante, o que sugeriria, até mesmo, certo espelhamento. Porém, se pensarmos na imagem especular como o duplo idêntico, veremos que essa não é uma definição que se aplique ao casal da narrativa. A eles caberia mais a imagem especular obtida pelo negativo, como na fotografia, em que as cores da foto revelada são inversas às inscritas na película fílmica.

Bóris tem 60 anos, é um empresário pragmático, de personalidade forte. É alguém que estabelece metas e as persegue, apresenta traços narcisistas e, constantemente, mostra-se impaciente. Dóris parece ser o oposto do marido. Ela tem 37 anos e é uma mulher sensível que abdicou da profissão para servir a ele. Mesmo discordando do que ele diz, Dóris parece não ter forças ou ânimo para se impor.

Grande parte da narrativa acontece durante um café da manhã em um hotel-fazenda onde o casal está hospedado. Desde o início da história, quando Bóris rejeita comer o bolo de chocolate sugerido por Dóris, pode-se perceber 0 tom divergente, às vezes irônico, outras vezes sarcástico, que irá perpassar toda a obra.

Enquanto Bóris espera pelo motorista que o levará a uma importante convenção, o casal conversa sobre assuntos variados que vão se interligando quase aleatoriamente, como 
num diálogo informal. O interessante é que um deles discorda de quase tudo o que é dito pelo outro e viceversa. Entre os temas por eles abordados, encontramos alguns polêmicos, como a pedofilia na Igreja Católica, e outros banais, como o motivo para o apelido do único irmão que Bóris tivera.

Com Boris e Dóris, Vilela convida-nos a refletir sobre a maneira como nossas subjetividades vêm à tona mesmo nas conversas mais banais. Seus personagens são construídos por meio de suas próprias falas. Bóris, imponente, tem falas longas, considera-se sempre com a razão e, quando a perde, ironiza. Dóris, muitas vezes, em respostas monossilábicas, começa discordando de Bóris, porém, vencida pelo cansaço ou sem disposição para defender seu ponto de vista, acaba concordando com o marido.

A estruturação do texto em diálogos, característica marcante do autor, garante a Bóris e Dóris uma leitura extremamente ágil. Essa rapidez de leitura, entretanto, não impede que o texto, em determinados momentos, adquira um ritmo cansativo. Várias falas são repetidas insistentemente como se o entendimento entre os personagens fosse algo dificil de se estabelecer. Esse caráter "enfadonho" (essa é, segundo as considerações de Dóris, uma das significações do nome de Bóris) torna-se parte integrante e necessária à construção do texto, pois, assim como a relação entre os dois parece estagnada, paralisada, de andamento dificultado, o texto que eles emitem também não pode fluir livremente.

Entre Bóris e Dóris já não há o que falar. O hiato da espera pelo motorista também serve como pretexto para o autor nos mostrar a banalidade que uma relação conjugal pode alcançar. A espera não é preenchida por uma conversa amigável, mas por uma série de farpas que marido e mulher lançam um contra o outro. Bóris e Dóris são dois estranhos que convivem; entretanto, já não coincidem. 